\title{
Dietary oils mediate cortisol kinetics and the hepatic mRNA expression profile of stress-responsive genes in gilthead sea bream (Sparus aurata) exposed to crowding stress. Implications on energy homeostasis and stress susceptibility
}

\section{Jaume Pérez-Sánchez ${ }^{1}$, Míriam Borrel ${ }^{1}$, Azucena Bermejo-Nogales ${ }^{1}$, Laura Benedito-Palos ${ }^{1}$, Alfonso Saera-Vila ${ }^{1}$, Josep A. Calduch-Giner ${ }^{1}$, Sadasivam Kaushik $^{2}$}

\author{
${ }^{I}$ Nutrigenomics and Fish Growth Endocrinology, Instituto de Acuicultura Torre de la Sal, IATS- \\ CSIC, Castellón, Spain \\ ${ }^{2}$ INRA, UR1067 NuMeA Nutrition, Metabolism Aquaculture, F64310 Saint Pée-sur Nivelle, \\ France
}

Corresponding author: Jaume Pérez-Sánchez

E-mail: jperez@iats.csic.es

Tel.: +34 964319500; Fax: +34964319509

\section{Running title: Nutritional background and stress challenges}

\begin{abstract}
Juveniles of gilthead sea bream were fed with plant protein-based diets with fish oil (FO diet) or vegetable oils (66VO diet) as dietary lipid sources. No differences in growth performance were found between both groups, and fish with an average body mass of 65-70 g were crowded (90$100 \mathrm{~kg} / \mathrm{m}^{3}$ ) to assess the stress response within the $72 \mathrm{~h}$ after the onset of stressor. The rise in plasma cortisol and glucose levels was higher in stressed fish of group 66VO (66VO-S) than in FO group (FO-S), but the former stressed group regained more quickly the cortisol resting values of the corresponding non-stressed diet group. The cell-tissue repair response represented by derlin-1, $75 \mathrm{kDa}$ glucose-regulated protein and $170 \mathrm{kDa}$ glucose-regulated protein was triggered at a lower level in 66VO-S than in FO-S fish. This occurred in concert with a longlasting up-regulation of glucocorticoid receptors, antioxidant enzymes, enzyme subunits of the mitochondrial respiratory chain, and enzymes involved in tissue fatty acid uptake and $\beta$ oxidation. This gene expression pattern allows a metabolic phenotype that is prone to "high
\end{abstract}


power" mitochondria, which would support the replacement of fish oil with vegetables oils when theoretical requirements in essential fatty acids for normal growth are met by diet.

Key words: stress transcriptomics, mitochondria, fish, fish oil, vegetable oil

Abbreviations used: AHR1 (aryl hydrocarbon receptor 1), CAT (catalase), Cox4a (cytochrome C oxidase subunit IV isoform 1), CPT1A (carnitine palmitoyltransferase 1A), CREB-2 (cyclic AMP response element-binding protein 2), CYP1A1 (cytochrome P450 1A1), DER-1 (derlin-1), EPA (eicosapentaenoic acid), DHA (docosahexaenoic acid), ECH (enoyl-CoA hydratase), ERdj3 (ER-associated Hsp40 co-chaperone), ER- $\alpha$ (estrogen receptor alpha), FA (fatty acid), HFABP (heart-fatty acid binding protein), GRC (glucocorticoid receptor), GRP-170 (170 kDa glucose-regulated protein), GRP-94 (94 kDa glucose-regulated protein), GRP-75 (75 kDa glucose-regulated protein), GPX1 (glutathione peroxidase 1), GPX4 (glutathione peroxidase 4), GR (glutathione reductase), GST3 (glutathione S-transferase 3), HL (hepatic lipase), HEPC (hepcidin), HSL (hormone-sensitive lipase), HADH (hydroxyacyl-CoA dehydrogenase), HIF-1 $\alpha$ (hypoxia inducible factor-1 alpha), LPL (lipoprotein lipase), LC-PUFA (n-3 long chain polyunsaturated fatty acids), LAL (lysosomal acid lipase), PRDX3 (peroxiredoxin 3), PRDX5 (peroxiredoxin 5), $\mathrm{Cu}-\mathrm{Zn}-\mathrm{SOD}$ (superoxide dismutase [Cu-Zn]), Mn-SOD (superoxide dismutase [Mn]), UCP1 (uncoupling protein 1).

\section{Introduction}

The continuous growth of global fish production necessitates less reliance on marine fish meal and fish oil as feed ingredients (Tacon and Metian, 2008; Watanabe, 2002). Plant proteins and oils constitute the obvious alternative and several studies have demonstrated the potential of the combined replacement of fish meal and fish oil in a wide range of farmed fish, including salmonids (Drew et al., 2007; Nasopoulou and Zabetakis, 2012; Pratoomyot et al., 2010; Torstensen et al., 2008) and typically marine fish, such as gilthead sea bream (Benedito-Palos et al., 2009; Benedito-Palos et al., 2008; Benedito-Palos et al., 2007). Certainly, relatively low inclusion levels of marine feed ingredients (less than 25-30\%) ensure normal growth and nutrient utilization in fast growing juveniles of gilthead sea bream. Such fish meal and fish oil replacement reduces the accumulation of feed-borne contaminants in the fish meat of cultured fish (Berntssen et al., 2005; Nácher-Mestre et al., 2010; 2009). However, vegetable oils are devoid of n-3 long chain polyunsaturated fatty acids (LC-PUFA) and marine fish fed such low fish oil diets have low contents in the healthy eicosapentaenoic acid (20:5n-3, EPA) and 
docosahexaenoic acid (22:6n-3, DHA), as it has been well described by mathematical models of fillet FA composition (Ballester-Lozano et al., 2011; Benedito-Palos et al., 2011).

Physiological well-being is also affected by the nutritional history and a general statement is that nutrient requirements for fish growth are different from those of immune function and health status (Montero and Izquierdo, 2011). Hence, in gilthead sea bream, the replacement of fish oil with vegetable oils is highly feasible when the theoretical requirements in essential fatty acids for normal growth are met by diet, but this dietary intervention allows a faster disease progression when fish are challenged with the intestinal parasite Enteromyxum leei (Estensoro et al., 2011; Calduch-Giner et al., 2012). Stress responsiveness and susceptibility are also nutritionally regulated, and a recent gilthead sea bream study highlights that the magnitude and persistence of high plasma cortisol levels after crowding exposure are dependent on the source of dietary oils (Ganga et al., 2011). However, it is difficult to define a general pattern of cortisol stress kinetics with the replacement of fish oil with vegetable oils. Thus, the present study addressed this complex issue in combination with the hepatic gene expression profiling of a set of 31 stress-responsive genes, selected as markers of lipid and lipoprotein metabolism, antioxidant defence system, cell-tissue repair mechanims, xenobiotic metabolism and stress transcriptional regulation. This set of markers was derived from a previous study underlying the liver microarray gene expression profiling of gilthead sea bream after crowding exposure (Calduch-Giner et al., 2010). Additional markers were identified by BLAST-searches for metabolic- and stress-relevant genes in the updated transcriptomic database of gilthead sea bream (www.nutrigroup-iats.org/seabreamdb). This search rendered 16 new gilthead sea bream sequences uploaded to GenBank with accession numbers JQ308820-JQ308835 (Supplemental Table 1).

\section{Materials and methods}

\subsection{Experimental setup}

Four hundred and eighty juveniles of gilthead sea bream (Sparus aurata, initial body mass $17 \mathrm{~g}$ ) were randomly allocated in eight 500-L tanks (60 fish per tank) and reared from May to June (10 weeks) under the natural photoperiod and temperature conditions at our latitude $\left(40^{\circ} 5^{\prime} \mathrm{N}\right.$; $0^{\circ} 10^{\prime} \mathrm{E}$ ). Two groups ( 4 replicates each) were established by feeding fish to visual satiety with plant protein-based diets with either fish oil (FO diet) or a blend of vegetable oils at the $66 \%$ of replacement of fish oil (66VO diet) as the most important source of dietary lipids (for details of diet composition see Benedito-Palos et al., 2007). As expected, no effect of diet composition 
was found on growth or nutrient utilisation and both dietary groups (65-70 $\mathrm{g}$ final body mass) had high growth rates (SGR = 1.8-1.9) and good feed:gain ratios (1-1.1).

Feeding was stopped one day before crowding challenge start. At that point, three replicates from each dietary group $\left(9-10 \mathrm{~kg} / \mathrm{m}^{3}\right)$ remained undisturbed (control fish), whereas the remaining replicate was used as a donor tank of stressed fish, according to the protocol conducted in previous studies (Calduch-Giner et al., 2010; Saera-Vila et al., 2009b) and summarized in Fig. 1. Briefly, for each diet group, seven batches of seven fish from the donor tank were used as stressed fish by transferring all of them at the same time to seven cylinder net baskets of 5-L volume (90-100 kg/m $\mathrm{m}^{3}$, each one suspended in 90-L tanks with a seawater flow of $10-\mathrm{L} / \mathrm{min}$ to ensure good water quality (oxygen $>5 \mathrm{ppm}$; unionised ammonia $<0.02 \mathrm{mg} / \mathrm{L}$ ). These stressed fish were sampled for blood ( $1 \mathrm{~h}, 2 \mathrm{~h}, 4.5 \mathrm{~h}$ and $6.5 \mathrm{~h})$ or blood and liver $(3 \mathrm{~h}, 24$ $\mathrm{h}$ and $72 \mathrm{~h}$ ) at fixed times after stressor onset. In parallel, fish from control tanks were sampled for blood and liver at $3 \mathrm{~h}, 24 \mathrm{~h}$ or $72 \mathrm{~h}$.

No mortality was registered during the course of the crowding period. At each sampling time, fish from control (FO-C, 66VO-C) and stressed (FO-S, 66VO-S) groups were netted into a bucket containing $0.1 \mathrm{~g} / \mathrm{L}$ of 3-aminobenzoic acid ethyl ester (MS-222; Sigma-Aldrich, St. Louis, MO, USA). Blood was taken from caudal vessels (in less than $2 \mathrm{~min}$ for all fish), centrifuged at $3000 \mathrm{~g}$ for $20 \mathrm{~min}$ at $4{ }^{\circ} \mathrm{C}$, and plasma samples were frozen and stored at $-20^{\circ} \mathrm{C}$ until analyses. Prior to tissue collection, fish were killed by cervical section and the liver was then rapidly extracted, frozen in liquid nitrogen and stored at $-80^{\circ} \mathrm{C}$ until RNA isolation. All procedures were carried out according to national (Consejo Superior de Investigaciones Científicas, Institute of Aquaculture Torre de la Sal Review Board) and the current EU legislation on the handling of experimental animals.

\subsection{Biochemical assays}

Plasma cortisol levels were measured using an EIA kit (Diagnostic Systems Laboratories, Webster, TX, USA) as reported elsewhere in gilthead sea bream and other fish species (Bermejo-Nogales et al., 2007; Kumar et al., 2011; Pereira Maduenho and Martinez, 2008). The assay is based on the competition between unlabelled cortisol and cortisol-horseradish peroxidase for a fixed number of antibody-binding sites. The tetramethylbenzidine was used as a chromogen solution, and the limit of detection of the assay was $1 \mathrm{ng} / \mathrm{mL}$ with $\mathrm{ED}_{20}$ and $\mathrm{ED}_{80}$ values of $100 \mathrm{ng} / \mathrm{mL}$ and $2 \mathrm{ng} / \mathrm{mL}$, respectively. The coefficient of variation intra- and interassay was lower than $8 \%$ and $12 \%$, respectively. Plasma glucose levels were measured by the glucose oxidase method (Thermo Electron, Louisville, CO, USA) as reported elsewhere (Bermejo-Nogales et al., 2007; Saera-Vila et al., 2009b). 


\subsection{Gene expression analysis}

Total RNA from liver was extracted with the ABI PRISM ${ }^{\text {TM }} 6100$ Nucleic Acid PrepStation (Applied Biosystems, Foster City, CA, USA) with a DNAse step. The RNA yield was 30-50 $\mathrm{g}$ with absorbance measures $\left(\mathrm{A}_{260 / 280}\right)$ of 1.9-2.1 and RIN (RNA integrity number) values of 8-10 with the Agilent 2100 Bioanalyzer, which is indicative of clean and intact RNA. Reverse transcription (RT) of $500 \mathrm{ng}$ total RNA was performed with random decamers, using the HighCapacity cDNA Archive Kit (Applied Biosystems) following manufacturer's instructions. Negative control reactions were run without reverse transcriptase and real-time quantitative PCR was carried out with an iCycler IQ Real-time Detection System (Bio-Rad, Hercules, CA, USA) as described earlier (Calduch-Giner et al., 2003). Briefly, RT reactions were conveniently diluted and the equivalent of $660 \mathrm{pg}$ of total input RNA was used in a $25 \mu \mathrm{L}$ volume for each PCR reaction. PCR-wells contained a 2x SYBR Green Master Mix (Bio-Rad) and specific primers at a final concentration of $0.9 \mu \mathrm{M}$ were used to obtain amplicons of 50-150 bp in length (Supplemental Table 2). The program used for PCR included an initial denaturation step of 95 ${ }^{\circ} \mathrm{C}$ for $3 \mathrm{~min}$, followed by 40 cycles of denaturation for $15 \mathrm{~s}$ at $95^{\circ} \mathrm{C}$ and annealing/extension for $60 \mathrm{~s}$ at $60^{\circ} \mathrm{C}$. The efficiency of PCR reactions was always higher than $90 \%$ and negative controls without sample templates were routinely performed for each primer set. The specificity of the reactions was verified by analysis of melting curves (ramping rates of $0.5^{\circ} \mathrm{C} / 10 \mathrm{~s}$ over a temperature range of $55-95^{\circ} \mathrm{C}$, yielding a single peak for each sample and gene), linearity of serial dilutions of RT reactions, and electrophoresis and sequencing of PCR amplified products. PCR reactions were performed in triplicate and the fluorescence data acquired during the extension phase were normalized by the delta-delta $\mathrm{Ct}$ method using $\beta$-actin as housekeeping gene (Livak and Schmittgen, 2001). Four genes ( $\beta$-actin, elongation factor $1, \alpha$-tubulin and 18S rRNA) were tested for stability using the GeNorm software. The most stable gene in relation to dietary treatment and crowding exposure was $\beta$-actin $(\mathrm{M}$ score $=0.21)$ and, thereby, it was used as housekeeping gene in the normalization procedure. When each dietary group was considered individually, fold-change calculations for each gene were referred to the expression ratio between stressed and control fish (values $>1$ indicates stress up-regulated genes; values $<1$ indicates stress down-regulated genes). For multi-gene analysis comparing the mRNA gene expression between stressed fish of the two diet groups, all data values were referred to the expression level of AHR1 in non-stressed fish of the FO diet group (arbitrarily referred as 1).

\subsection{Statistical analysis}


Stress and nutritionally-mediated effects in hepatic mRNA transcripts and circulating levels of cortisol and glucose were analysed by Student t-test at a significance level of 5\%. All analyses were made using the SPSS package version 19.0 (SPSS Inc., Chicago, IL, USA).

\section{Results}

\subsection{Plasma cortisol and glucose kinetics}

Plasma cortisol levels in control fish remained almost unchanged during the course of the stress challenge, though overall cortisol titres were 3 -fold higher in 66VO-C fish $(20-35 \mathrm{ng} / \mathrm{mL})$ than in FO-C fish (3-11 ng/mL). In both dietary groups, plasma cortisol levels rapidly increased after crowding exposure, and the peak of cortisol was 2- to 3- fold higher in fish fed the 66VO diet (66VO-S group) than in the stressed fish of the FO diet group (FO-S group) (Fig. 2A). A recovery of cortisol resting values was found at $24 \mathrm{~h}$ after the induction of crowding stress in 66VO-S fish, whereas persistently high plasma cortisol levels were observed in FO-S fish. Glycaemia remained almost unchanged in control fish $(60-80 \mathrm{mg} / \mathrm{dL})$ with no effects of diet composition on the measured values. In both dietary groups, plasma glucose levels increased rapidly after crowding exposure with a maximum at 1-3 $\mathrm{h}$ and a recovery towards control values at $24 \mathrm{~h}$ (Fig. 2B). However, the magnitude of response was dependent on the nutritional background and the peak of glycaemia $(>200 \mathrm{mg} / \mathrm{dL}$ ) in 66VO-S fish was significantly higher $(\mathrm{P}<0.05)$ than in FO-S fish $(130-150 \mathrm{mg} / \mathrm{dL})$.

\subsection{Hepatic gene expression}

The time course of the liver transcriptional response was analysed for each gene at 3, 24 and 72 $\mathrm{h}$ after crowding exposure and fold-changes in mRNA transcript levels were referred to the control group of non-stressed fish for each diet and sampling time (Fig. 3). Overall, the strongest up-regulated changes in mRNA transcript levels were found $24 \mathrm{~h}$ after confinement, which was particularly evident for some cell- and tissue-repairing genes (derlin-1, DER-1; estrogen receptor-associated Hsp40 co-chaperone, ERdj3; 94 kDa glucose-regulated protein, GRP-94; and 170 kDa glucose-regulated protein, GRP-170), antioxidant enzymes (glutathione peroxidase 4, GPX4; peroxiredoxin 3, PRDX3; superoxide dismutases, $\mathrm{Cu}-\mathrm{Zn}-\mathrm{SOD}$ and MnSOD), nuclear receptors (estrogen receptor alpha, ER- $\alpha$; glucocorticoid receptor, GCR) and transcription factors (cyclic AMP response element-binding protein 2, CREB-2; hypoxia inducible factor-1 alpha, HIF-1 $\alpha$ ). Most gene markers of lipid and lipoprotein metabolism (carnitine palmitoyltransferase 1A, CPT1A; hydroxyacyl-CoA dehydrogenase, HADH; heartFA binding protein, H-FABP; hepatic lipase, HL; hormone-sensitive lipase, HSL; lysosomal 
acid lipase, LAL) were also strongly up-regulated at $24 \mathrm{~h}$ after crowding exposure, though in the case of lipoprotein lipase (LPL) the maximum response was attained earlier ( $3 \mathrm{~h}$ after crowding exposure). Likewise, aryl hydrocarbon receptor 1 (AHR1) was transiently up-regulated at $24 \mathrm{~h}$ after crowding exposure, whereas other xenobiotic gene markers (cytochrome P450 1A1, CYP1A1; glutathione S-transferase 3, GST3) were mostly down-regulated within the $72 \mathrm{~h}$ after the onset of stressor disturbance.

The stress-transcriptional response was also modulated by the nutritional history and overall the magnitude of change was quantitatively and qualitatively higher in the FO diet group (Fig. 3A) than in 66VO fish (Fig. 3B). Thus, with the exception of glutathione peroxidase 1 (GPX1), the expression profile of all the measured genes was transcriptionally regulated by stress confinement in at least one sampling time in FO-S fish. In contrast, in 66VO-S fish, up to 5 genes, including cytochrome c oxidase subunit IV isoform 1 (Cox4a), enoyl-CoA hydratase $(\mathrm{ECH})$, uncoupling protein 1 (UCP1), catalase (CAT) and GST3 did not vary significantly at any sampling time when data were referred to the corresponding diet control group.

When gene expression levels from the two stressed groups of fish were plotted against each other (FO-S vs 66VO-S), the results rendered a gene expression pattern changing over time from a down- to up-regulated adjustment in stressed fish of the 66VO diet. Hence, at $3 \mathrm{~h}$ after the onset of the stressor disturbance, CAT, Cox4a, CYP1A1, Cu-Zn-SOD, DER-1, PRDX3 and glutathione reductase (GR) were significantly down-regulated in 66VO-S fish in comparison to the FO-S group (Fig. 4A). At $24 \mathrm{~h}$ after crowding exposure, differentially expressed genes were either down- (DER-75; 75 kDa glucose-regulated protein, GRP-75; GRP-170 and Cox4a) or upregulated (ECH, ER- $\alpha, \mathrm{HADH}$, and GCR) (Fig. 4B) in 66VO-S fish, whereas later on (72h) all the differentially expressed genes (GR, Cox4a, GCR, HADH, PRDX3, LPL; peroxiredoxin 5, PRDX5) were up-regulated in 66VO-S fish in comparison to FO-S group (Fig. 4C).

\section{Discussion}

The magnitude and duration of cortisol response is fish species-specific and highly dependent on the type, intensity and duration of the stressor as well as on the background history of the animal (Barton et al., 2002; Iwama et al., 2006; Wendelaar-Bonga, 1997). For instance, exposure to the same stressor resulted in higher cortisol levels in brown trout than in rainbow trout (Barton, 2002; Ruane et al., 1999). Similarly, plasma cortisol levels after chasing (5-6 min) and air exposure (1-1.5 min) are 2- to 4-fold higher in European sea bass than in gilthead sea bream and other sparid fish (Fanouraki et al., 2011). Available data also indicate that in most fish species, including gilthead sea bream, peak cortisol levels are reached between $30 \mathrm{~min}$ and $1 \mathrm{~h}$ with a 
recovery of resting values within 2-48 h of the initial disturbance (Arends et al., 1999; Rotllant et al., 2000; Rotllant et al., 2001). Longer recovery times with bimodal cortisol-rises have been reported in response to crowding at stocking densities of $50 \mathrm{~kg} / \mathrm{m}^{3}$ (Ganga et al., 2011) and 120 $\mathrm{kg} / \mathrm{m}^{3}$ (Saera-Vila et al., 2009b). In the present study, a second peak of cortisol was not found in fish allocated at an intermediate density of $90-100 \mathrm{~kg} / \mathrm{m}^{3}$, but intriguingly the cortisol-rise in stressed fish of FO diet group was of low magnitude reaching a plateau that did not regain the diet control values within the $72 \mathrm{~h}$ after the onset of stressor disturbance. The physiological significance of this finding remains controversial, though it can be viewed as a variant of a bimodal cortisol-rise or an artifactual result of a true bimodal response due to the limited number of sampling points over the course of the experimental period. Anyway, stressed fish fed the 66VO diet showed a high and well-defined cortisol peak, accompanied of a high hyperglycemic response that highlights an overactive glucocorticoid system in fish fed a blend of vegetable oils as the most important source of dietary lipids.

The above findings confirm and extend the idea pointed out by Ganga et al. (2011) that dietary oils largely mediate cortisol kinetics in gilthead sea bream. If this assessment is indicative of a different stress susceptibility is, thereby, open to discussion. However, given that both FO and $66 \mathrm{VO}$ diets support a normal growth in gilthead sea bream, it is likely that the nutritionalmediated effects in cortisol kinetics are adaptive rather than maladaptive, serving to assure in each physiological condition the most efficient management of the "allostatic load", defined as the process that maintains stability through change of a number of stress mediators, including hormones (e.g. cortisol, catecholamines, pituitary hormones, insulin), immune factors and heat shock proteins (McEwen, 2002; Sterling and Eyer, 1998). In other words, fish, and gilthead seam bream in particular, might conveniently adjust the stress response to a specific nutritional background and risk of oxidative stress, which is primarily the result of the tissue FA unsaturation index that experiences an overall decrease with the replacement of fish oil with vegetable oils (Benedito-Palos et al., 2010). Supporting this, total glutathione levels are reduced in gilthead sea bream fed high levels of vegetable oils (Saera-Vila et al., 2009a), but intriguinlgy these fish also show a concurrent increase of the glutathione reduced/oxidized (GSH/GSSG) ratio, which is recognized as a reliable marker of a reduced risk of oxidative stress.

Additional support for nutritional stress resilience is coming from the gene expression profiling of liver. Certainly, the advent of microarray gene expression technology has revealed a wide range of stress-responsive genes in response to a number of aquaculture stressors (Aluru and Vijayan, 2009). In particular for gilthead sea bream (Calduch-Giner et al., 2010), the microarray gene expression profiling of crowding stress underscores three major steps leading to i) rapid enhancement of energy supply, ii) strong activation of tissue repair and remodeling processes 
and iii) re-establishment of redox balance with increased scavenging of reactive oxygen species (ROS) and a general decline of ROS production. Such temporal gene expression pattern was exemplified herein by the strong activation $24 \mathrm{~h}$ after stressor disturbance of the cell-tissue repair response that assists mitochondria and ER protein-folding and misfolding. This transcriptional feature was especially evident in the FO diet group not only when the gene expression values of stressed fish were referred to the control dietary group (Fig. 3), but also when the expression data of the two stressed groups was referred to each other in separate scatter plots for each sampling time (Fig. 4). According to this, the repair-response of DER-1, GRP-170 and GRP-75, also termed mortalin or mitochondrial HSP70, was triggered at a lowest level in stressed fish of the 66VO diet group (Fig. 4B). Of note, DER-1 elicits ER-associated degradation (Lilley and Ploegh, 2004), whereas GRP-170 (Chen et al., 1996; Park et al., 2003) is a molecular ER chaperone that assists the folding of nascent chains and help to achieve an active conformation for mature proteins. GRP-75 is found in ER, cytosol and cytoplasmic vesicles, though it is primarily of mitochondrial origin and its expression is triggered by glucose deprivation, oxidative injury, ionizing radiation, calcium ionophores and hyperthyroidism (Wadhwa, 2002; Wadhwa et al., 2002). It also performs a broad spectrum of cellular functions ranging from stress response, intracellular trafficking, antigen processing, and cell differentiation and proliferation that makes GRP-75 and its yeast homologue (SSC1p) lifeessential (Craig et al., 1989; Kaul et al., 2007). This also applies to fish species and GRP-75deficient mutants of zebrafish have serious blood developmental defects (Craven et al., 2005). In the same line, experimental evidence indicates that both protein and mRNA GRP-75 expression is highly inducible by acute and chronic stressors in the liver tissue of gilthead sea bream (Bermejo-Nogales et al., 2008). Besides, the hepatic expression of this protein remains specially elevated in the liver tissue of common dentex (Bermejo-Nogales et al., 2007), a closely related sparid fish with stressful behavior, low larval survival and increased susceptibility to opportunistic pathogens (Company et al., 1999; Pujalte et al., 2003; Sitjà-Bobadilla et al., 2007). As reported for GRP-75, there are many lines of evidence supporting a key role of many other mitochondrial-related genes in acute and chronic allostatic states leading to explain the differences in stress susceptibility among individuals and animal species (Manoli et al., 2007). Strong support for this notion comes from inbreeding selection of rat strains with "low power" versus "high power" mitochondria, which demonstrates that most stressful and health risk factors segregate with low expression levels of genes required for mitochondrial biogenesis and oxidative phosphorylation (Wisløff et al., 2005). Likewise, the prophylactic role of calorie restriction and exercise is due, at least in part, to the induction of antioxidant enzymes, heat shock proteins, and mitochondrial oxidative phosphorylation (Arumugam et al., 2006; Mattson 
and Kroemer, 2003). Extrapolation of these results to other animal models is always difficult, but it is noteworthy that mitochondrial antioxidant enzymes, including the recently characterized gilthead sea bream PRDX3 and PRDX5 (Pérez-Sánchez et al., 2011), were long-lasting upregulated in stressed fish of the 66VO diet group (Fig. 4C). This gene expression pattern was accompanied by the up-regulation of markers of $\beta$-oxidation (HADH), tissue FA uptake (LPL) and oxidative phosphorylation (Cox4a), which is prone to a phenotype of "high power" mitochondria also challenged by the finding that the cell-repair machinery seems to be triggered at a reduced level in stressed fish fed the 66VO diet (Fig. 4B).

Other important stress-responsive genes are CREB-2 (Chin, 2008; Karpinski et al., 1992) and HIF-1 $\alpha$ (Tekin et al., 2010), and their up-regulation at $24 \mathrm{~h}$ after the onset of stressor disturbance might orchestrate the overall and strong activation of the transcriptional machinery at this specific steady state. However, the stress responsiveness of these two upstream transcriptional regulatory factors was not differentially regulated by dietary oils, and other factors would contribute to explain the above differences in stress transcriptomics. In this context, it is noteworthy that the modulation of mitochondrial activity by glucocorticoids is considered biphasic with an initial induction of mitochondrial biogenesis and enzymatic activities of selected subunits of the respiratory chain complexes, whereas chronic exposure to high glucocorticoid levels causes respiratory chain dysfunction, increased ROS production, mitochondrial structural abnormalities, apoptosis and cell death (Adzic et al., 2009; Alesci et al., 2006; Manoli et al., 2007). The mechanisms by which GCRs interact with the nuclear and mitochondrial transcription machinery remain largely unknown, especially in fish, though important progress has been made in last years in this field (Aluru and Vijayan, 2009; Schaaf et al., 2009). In our experimental model, the expression of GCRs was consistently up-regulated in stressed fish of the 66VO diet group in comparison to those of the FO diet group ( $24 \mathrm{~h}$ and $72 \mathrm{~h}$ after the onset of stressor disturbance) (Fig. 4B). Therefore, although we have no data on the expression of protein GCRs, this transcriptional measure also supports that fish fed high levels of vegetable oils are prone to have an overactive glucocorticoid system with an enhanced hyperglycemic response when facing stressors.

In summary, the stress response is highly mediated at the nutritional level in gilthead sea bream. If the observed changes in stress kinetics and responsiveness are beneficial or detrimental for fish fed vegetal oils is not easy to answer due to the technical limitations of our experimental approach to ultimately asses the cellular stress response at the tertiary level. However, taken as a whole the fish performance, the risk of oxidative stress and the mRNA expression profile of gene markers of mitochondrial activity and cell-tissue repair response, it appears that the response to crowding stress in fish fed the $66 \mathrm{VO}$ diet is prone to be a permissive rather than a 
constraining factor for the replacement of fish oil with vegetable oils when the theoretical requirements in essential fatty acids for normal growth are met by diet. The precise mechanism remains still elusive, but it can be argued that fish fed vegetable oils allow a strong glucocorticoid response, whereas fish fed fish oil lead a lower but perhaps more persistent response in order to avoid tissue damage in a tissue-cell milieu with a higher risk of oxidative stress. The practical implications for the aquaculture industry are obvious since growth performance is becoming a more restrictive factor than stress susceptibility when facing the replacement of fish oil with alternative oils in a warm marine fish highly cultured in all the Mediterranean area.

Acknowledgements. This work was funded by the EU projects AQUAEXCEL (Aquaculture Infrastructures for Excellence in European Fish Research, FP7/2007/2013; grant agreement $n^{\circ}$ 262336), and ARRAINA (Advanced Research Initiatives for Nutrition \& Aquaculture, FP7/2007/2013; grant agreement $n^{\circ} 288925$ ), and the Spanish project AQUAGENOMICS (CSD2007-00002, Improvement of Aquaculture Production by the Use of Biotechnological Tools). Additional funding was obtained from the "Generalitat Valenciana" (research grant PROMETEO 2010/006). The authors are grateful to M.A. González for the excellent technical assistance in PCR analyses.

\section{References}

Adzic, M., Djordjevic, A., Demonacos, C., Krstic-Demonacos, M., Radojcic, M.B., 2009. The role of phosphorylated glucocorticoid receptor in mitochondrial functions and apoptotic signalling in brain tissue of stressed Wistar rats. Int. J. Biochem. Cell Biol. 41, 2181-2188.

Alesci, S., Manoli, I., Michopoulos, V.J., Brouwers, F.M., Le, H., Gold, P.W., Blackman, M.R., Rennert, O.M., Su, Y.A., Chrousos, G.P., 2006. Development of a human mitochondria-focused cDNA microarray (hMitChip) and validation in skeletal muscle cells: implications for pharmaco- and mitogenomics. Pharmacogenomics J 6, 333-342.

Aluru, N., Vijayan, M.M., 2009. Stress transcriptomics in fish: A role for genomic cortisol signaling. Gen Comp Endocrinol 164, 142-150.

Arends, R.J., Mancera, J.M., Muñoz, J.L., Wendelaar-Bonga, S.E., Flik, G., 1999. The stress response of the gilthead sea bream (Sparus aurata L.) to air exposure and confinement. J Endocrinol 163, 149-157.

Arumugam, T.V., Gleichmann, M., Tang, S.C., Mattson, M.P., 2006. Hormesis/preconditioning mechanisms, the nervous system and aging. Ageing Res Rev 5, 165-178.

Ballester-Lozano, G.F., Benedito-Palos, L., Navarro, J.C., Kaushik, S., Pérez-Sánchez, J., 2011. Prediction of fillet fatty acid composition of market-size gilthead sea bream (Sparus aurata) using a regression modelling approach. Aquaculture 319, 81-88. 
Barton, B., Morgan, J.D., Vijayan, M., 2002. Physiological and condition-related indicators of environmental stress in fish, in: S.M. Adams (Ed.), Biological indicators of stress in fish (2nd ed.), Bethesda, Maryland, 111-148.

Barton, B.A., 2002. Stress in Fishes: A diversity of responses with particular reference to changes in circulating corticosteroids. Integr Comp Biol 42, 517-525.

Benedito-Palos, L., Bermejo-Nogales, A., Karampatos, A.I., Ballester-Lozano, G.F., Navarro, J.C., Diez, A., Bautista, J.M., Bell, J.G., Tocher, D.R., Obach, A., Kaushik, S., Pérez-Sánchez, J., 2011. Modelling the predictable effects of dietary lipid sources on the fillet fatty acid composition of one-year-old gilthead sea bream (Sparus aurata L.). Food Chem. 124, 538-544.

Benedito-Palos, L., Navarro, J.C., Kaushik, S., Pérez-Sánchez, J., 2010. Tissue-specific robustness of fatty acid signatures in cultured gilthead sea bream (Sparus aurata L.) fed practical diets with a combined high replacement of fish meal and fish oil. J Anim Sci 88, 1759-1770.

Benedito-Palos, L., Navarro, J.C., Bermejo-Nogales, A., Saera-Vila, A., Kaushik, S., Pérez-Sánchez, J., 2009. The time course of fish oil wash-out follows a simple dilution model in gilthead sea bream (Sparus aurata L.) fed graded levels of vegetable oils. Aquaculture 288, 98-105.

Benedito-Palos, L., Navarro, J.C., Sitjà-Bobadilla, A., Bell, J.G., Kaushik, S., Pérez-Sánchez, J., 2008. High levels of vegetable oils in plant protein-rich diets fed to gilthead sea bream (Sparus aurata L.): growth performance, muscle fatty acid profiles and histological alterations of target tissues. $\mathrm{Br}$ J Nutr 100, 992-1003.

Benedito-Palos, L., Saera-Vila, A., Calduch-Giner, J.A., Kaushik, S., Pérez-Sánchez, J., 2007. Combined replacement of fish meal and oil in practical diets for fast growing juveniles of gilthead sea bream (Sparus aurata L.): Networking of systemic and local components of GH/IGF axis. Aquaculture 267, 199-212.

Bermejo-Nogales, A., Benedito-Palos, L., Saera-Vila, A., Calduch-Giner, J.A., Sitjà-Bobadilla, A., Pérez-Sánchez, J., 2008. Confinement exposure induces glucose regulated protein 75 (GRP75/mortalin/mtHsp70/PBP74/HSPA9B) in the hepatic tissue of gilthead sea bream (Sparus aurata L.). Comp Biochem Physiol B 149, 428-438.

Bermejo-Nogales, A., Saera-Vila, A., Calduch-Giner, J.A., Navarro, J.C., Sitjà-Bobadilla, A., PérezSánchez, J., 2007. Differential metabolic and gene expression profile of juvenile common dentex (Dentex dentex L.) and gilthead sea bream (Sparus aurata L.) in relation to redox homeostasis. Aquaculture 267, 213-224.

Berntssen, M.H.G., Lundebye, A.K., Torstensen, B.E., 2005. Reducing the levels of dioxins and dioxinlike PCBs in farmed Atlantic salmon by substitution of fish oil with vegetable oil in the feed. Aquacult Nutr 11, 219-231.

Calduch-Giner, J., Davey, G., Saera-Vila, A., Houeix, B., Talbot, A., Prunet, P., Cairns, M., PérezSánchez, J., 2010. Use of microarray technology to assess the time course of liver stress response after confinement exposure in gilthead sea bream (Sparus aurata L.). BMC Genomics 11, 193.

Calduch-Giner, J., Sitjà-Bobadilla, A., Davey, G., Cairns, M., Kaushik, S., Pérez-Sánchez, J., 2012. Dietary vegetable oils do not alter the intestine transcriptome of gilthead sea bream (Sparus aurata), but modulate the transcriptomic response to infection with Enteromyxum leei. BMC Genomics 13, 470.

Calduch-Giner, J.A., Mingarro, M., Vega-Rubín de Celis, S., Boujard, D., Pérez-Sánchez, J., 2003. Molecular cloning and characterization of gilthead sea bream, (Sparus aurata) growth hormone receptor (GHR). Assessment of alternative splicing. Comp Biochem Physiol B 136, 1-13.

Chen, X., Easton, D., Oh, H.-J., Lee-Yoon, D.-S., Liu, X., Subjeck, J., 1996. The 170 kDa glucose regulated stress protein is a large HSP70- HSP110-like protein of the endoplasmic reticulum. FEBS Lett 380, 68-72. 
Chin, M.T., 2008. ATF-4 and vascular injury - Integration of growth factor signaling and the cellular stress response. Circ Res 103, 331-333.

Company, R., Sitjà-Bobadilla, A., Pujalte, M.J., Garay, E., Alvarez-Pellitero, P., Pérez-Sánchez, J., 1999. Bacterial and parasitic pathogens in cultured common dentex, Dentex dentex L. J Fish Dis 22 , 299-309.

Craig, E.A., Kramer, J., Shilling, J., Werner-Washburne, M., Holmes, S., Kosic-Smithers, J., Nicolet, C.M., 1989. Ssc1, an essential member of the yeast Hsp70 multigene family, encodes a mitochondrial protein. Mol Cell Biol 9, 3000-3008.

Craven, S.E., French, D., Ye, W., de Sauvage, F., Rosenthal, A., 2005. Loss of Hspa9b in zebrafish recapitulates the ineffective hematopoiesis of the myelodysplastic syndrome. Blood 105, 35283534.

Drew, M.D., Ogunkoya, A.E., Janz, D.M., Van Kessel, A.G., 2007. Dietary influence of replacing fish meal and oil with canola protein concentrate and vegetable oils on growth performance, fatty acid composition and organochlorine residues in rainbow trout (Oncorhynchus mykiss). Aquaculture 267, 260-268.

Estensoro, I., Benedito-Palos, L., Palenzuela, O., Kaushik, S., Sitjà-Bobadilla, A., Pérez-Sánchez, J., 2011. The nutritional background of the host alters the disease course in a fish-myxosporean system. Vet Parasitol 175, 141-150.

Fanouraki, E., Mylonas, C.C., Papandroulakis, N., Pavlidis, M., 2011. Species specificity in the magnitude and duration of the acute stress response in Mediterranean marine fish in culture. Gen Comp Endocrinol 173, 313-322.

Ganga, R., Montero, D., Bell, J.G., Atalah, E., Ganuza, E., Vega-Orellana, O., Tort, L., Acerete, L., Afonso, J.M., Benitez-Sanatana, T., Fernández Vaquero, A., Izquierdo, M., 2011. Stress response in sea bream (Sparus aurata) held under crowded conditions and fed diets containing linseed and/or soybean oil. Aquaculture 311, 215-223.

Iwama, G.K., Afonso, L.O.B., Vijayan, M., 2006. Stress in fish, in: D.H. Evans, J.B. Claiborne (Eds.), The physiology of fishes (Third ed.). CRC Press, Boca Raton, Florida, 319-342.

Karpinski, B.A., Morle, G.D., Huggenvik, J., Uhler, M.D., Leiden, J.M., 1992. Molecular-cloning of human creb-2 - an atf/creb transcription factor that can negatively regulate transcription from the camp response element. Proc Natl Acad Sci USA 89, 4820-4824.

Kaul, S.C., Deocaris, C.C., Wadhwa, R., 2007. Three faces of mortalin: A housekeeper, guardian and killer. Exp Gerontol 42, 263-274.

Kumar, N., Prabhu, P.A.J., Pal, A.K., Remya, S., Aklakur, M., Rana, R.S., Gupta, S., Raman, R.P., Jadhao, S.B., 2011. Anti-oxidative and immuno-hematological status of tilapia (Oreochromis mossambicus) during acute toxicity test of endosulfan. Pestic Biochem Physiol 99, 45-52.

Lilley, B.N., Ploegh, H.L., 2004. A membrane protein required for dislocation of misfolded proteins from the ER. Nature 429, 834-840.

Livak, K.J., Schmittgen, T.D., 2001. Analysis of relative gene expression data using real-time quantitative PCR and the $2^{-\Delta \Delta C}$ T method. Methods 25, 402-408.

Manoli, I., Alesci, S., Blackman, M.R., Su, Y.A., Rennert, O.M., Chrousos, G.P., 2007. Mitochondria as key components of the stress response. Trends Endocrinol. Metab. 18, 190-198.

Mattson, M.P., Kroemer, G., 2003. Mitochondria in cell death: novel targets for neuroprotection and cardioprotection. Trends Mol Med 9, 196-205.

McEwen, B.S., 2002. Sex, stress and the hippocampus: allostasis, allostatic load and the aging process. Neurobiol. Aging 23, 921-939. 
Montero, D., Izquierdo, M., 2011. Welfare and health of fish fed vegetable oils as alternative lipid sources to fish oil, in: G.M. Turchini, W.K. Ng, D.R. Tocher (Eds.), Fish oil replacement and alternative lipid sources in aquaculture feeds. CRC Press, Boca Raton, FL, 439-486.

Nácher-Mestre, J., Serrano, R., Benedito-Palos, L., Navarro, J.C., López, F.J., Kaushik, S., PérezSánchez, J., 2010. Bioaccumulation of polycyclic aromatic hydrocarbons in gilthead sea bream (Sparus aurata L.) exposed to long term feeding trials with different experimental diets. Arch. Environ. Contam. Toxicol. 59, 137-146.

Nácher-Mestre, J., Serrano, R., Benedito-Palos, L., Navarro, J.C., López, F.J., Pérez-Sánchez, J., 2009. Effects of fish oil replacement and re-feeding on the bioaccumulation of organochlorine compounds in gilthead sea bream (Sparus aurata L.) of market size. Chemosphere 76, 811-817.

Nasopoulou, C., Zabetakis, I., 2012. Benefits of fish oil replacement by plant originated oils in compounded fish feeds. A review. LWT-Food Sci Technol 47, 217-224.

Park, J., Easton, D.P., Chen, X., MacDonald, I.J., Wang, X.-Y., Subjeck, J.R., 2003. The chaperoning properties of mouse Grp170, a member of the third family of Hsp70 related proteins. Biochemistry 42, 14893-14902.

Pereira Maduenho, L., Martinez, C.B.R., 2008. Acute effects of diflubenzuron on the freshwater fish Prochilodus lineatus. Comp Biochem Physiol C 148, 265-272.

Pérez-Sánchez, J., Bermejo-Nogales, A., Calduch-Giner, J.A., Kaushik, S., Sitjà-Bobadilla, A., 2011. Molecular characterization and expression analysis of six peroxiredoxin paralogous genes in gilthead sea bream (Sparus aurata): Insights from fish exposed to dietary, pathogen and confinement stressors. Fish Shellfish Immunol 31, 294-302.

Pratoomyot, J., Bendiksen, E.A., Bell, J.G., Tocher, D.R., 2010. Effects of increasing replacement of dietary fishmeal with plant protein sources on growth performance and body lipid composition of Atlantic salmon (Salmo salar L.). Aquaculture 305, 124-132.

Pujalte, M.J., Sitjà-Bobadilla, A., Macian, M.C., Belloch, C., Álvarez-Pellitero, P., Pérez-Sánchez, J., Uruburu, F., Garay, E., 2003. Virulence and molecular typing of Vibrio harveyi strains isolated from cultured dentex, gilthead sea bream and European sea bass. Syst Appl Microbiol 26, 284292.

Rotllant, J., Arends, R.J., Mancera, J.M., Flik, G., Wendelaar-Bonga, S.E., Tort, L., 2000. Inhibition of HPI axis response to stress in gilthead sea bream (Sparus aurata) with physiological plasma levels of cortisol. Fish Physiol Biochem 23, 13-22.

Rotllant, J., Balm, P.H.M., Pérez-Sánchez, J., Wendelaar-Bonga, S.E., Tort, L., 2001. Pituitary and interrenal function in gilthead sea bream (Sparus aurata L., Teleostei ) after handling and confinement stress. Gen Comp Endocrinol 121, 333-342.

Ruane, N.M., Wendelaar-Bonga, S.E., Balm, P.H.M., 1999. Differences between rainbow trout and brown trout in the regulation of the pituitary-interrenal axis and physiological performance during confinement. Gen Comp Endocrinol 115, 210-219.

Saera-Vila, A., Benedito-Palos, L., Sitjà-Bobadilla, A., Nácher-Mestre, J., Serrano, R., Kaushik, S., Pérez-Sánchez, J., 2009a. Assessment of the health and antioxidant trade-off in gilthead sea bream (Sparus aurata L.) fed alternative diets with low levels of contaminants. Aquaculture 296, 87-95.

Saera-Vila, A., Calduch-Giner, J.A., Prunet, P., Pérez-Sánchez, J., 2009b. Dynamics of liver GH/IGF axis and selected stress markers in juvenile gilthead sea bream (Sparus aurata) exposed to acute confinement. Differential stress response of growth hormone receptors. Comp Biochem Physiol A 154, 197-203.

Schaaf, M.J.M., Chatzopoulou, A., Spaink, H.P., 2009. The zebrafish as a model system for glucocorticoid receptor research. Comp Biochem Physiol A 153, 75-82. 
Sitjà-Bobadilla, A., Pujalte, M.J., Bermejo, A., Garay, E., Alvarez-Pellitero, P., Pérez-Sánchez, J., 2007. Bacteria associated with winter mortalities in laboratory-reared common dentex (Dentex dentex L.). Aquacult Res 38, 733-739.

Sterling, P., Eyer, J., 1998. Allostasis: a new paradigm to explain arousal pathology, in: S. Fisher, J. Reason (Eds.), Handbook of life stress, cognition and health. Wiley, New York, 629-649.

Tacon, A.G.J., Metian, M., 2008. Global overview on the use of fish meal and fish oil in industrially compounded aquafeeds: Trends and future prospects. Aquaculture 285, 146-158.

Tekin, D., Dursun, A.D., Xi, L., 2010. Hypoxia inducible factor 1 (HIF-1) and cardioprotection. Acta Pharmacol Sin 31, 1085-1094.

Torstensen, B.E., Espe, M., Sanden, M., Stubhaug, I., Waagbø, R., Hemre, G.I., Fontanillas, R., Nordgarden, U., Hevrøy, E.M., Olsvik, P., Berntssen, M.H.G., 2008. Novel production of Atlantic salmon (Salmo salar) protein based on combined replacement of fish meal and fish oil with plant meal and vegetable oil blends. Aquaculture 285, 193-200.

Wadhwa, R., 2002. An Hsp70 family chaperone, mortalin/mthsp70/PBP74/Grp75: what, when, and where? Cell Stress Chaperones 7, 309-316.

Wadhwa, R., Taira, K., Kaul, S.C., 2002. Mortalin: a potential candidate for biotechnology and biomedicine. Histol Histopathol 17, 1173-1177.

Watanabe, T., 2002. Strategies for further development of aquatic feeds. Fisher. Sci. 68, 242-252.

Wendelaar-Bonga, S.E., 1997. The stress response in fish. Physiol Revs 77, 591-625.

Wisløff, U., Najjar, S.M., Ellingsen, Ø., Haram, P.M., Swoap, S., Al-Share, Q., Fernström, M., Rezaei, K., Lee, S.J., Koch, L.G., Britton, S.L., 2005. Cardiovascular risk factors emerge after artificial selection for low aerobic capacity. Science 307, 418-420.

\section{Figure legends}

Figure 1. Scheme of the crowding stress protocol for fish fed FO or 66VO diets. Three replicates from each dietary group $\left(9-10 \mathrm{~kg} / \mathrm{m}^{3}\right)$ remained undisturbed (control fish), whereas the remaining replicate was used as donor of fish for the zero time and the following samplings. These later fish (S) were stressed by transferring them to cylinder net baskets of 5-L volume $\left(90-100 \mathrm{~kg} / \mathrm{m}^{3}\right)$ and sampled for blood or blood and liver within the $72 \mathrm{~h}$ after the onset of stressor. Fish from control tanks were sampled for blood and liver at $3 \mathrm{~h}, 24 \mathrm{~h}$ or $72 \mathrm{~h}$.

Figure 2. Effect of nutritional background on the time course of plasma cortisol (A) and glucose (B) stress responses in stressed fish of the 66VO diet group (white circles) and FO diet group (black circles). Data are the mean $\pm \operatorname{SEM}(\mathrm{n}=7)$. ${ }^{*}$, denotes significant differences $(\mathrm{P}<0.05)$ between stressed fish of the two dietary groups at a given sampling time. Control values are shown as two inserts. $\dagger$, denotes significant differences between control and stressed fish at $3 \mathrm{~h}$, $24 \mathrm{~h}$ and $72 \mathrm{~h}$ after crowding exposure.

Figure 3. Effect of nutritional background on the hepatic expression of stress-relevant genes at 3 $\mathrm{h}$ (black bars), $24 \mathrm{~h}$ (gray bars) and $72 \mathrm{~h}$ (white bars) after the onset of initial disturbance. Data are the mean $\pm \operatorname{SEM}(n=7)$. $\beta$-actin was used as a housekeeping gene. Each gene expression 
value in stressed fish of the FO diet group (A) and 66VO diet group (B) was referred for a given sampling time to each diet-control value. Data in control fish were used as arbitrary reference values (values $>1$ indicates stress up-regulated genes; values $<1$ indicates stress down-regulated genes). Asterisks indicate statistically significant differences $(\mathrm{P}<0.05)$ with respect to dietcontrol group at each sampling time.

Figure 4. Gene expression values in stressed fish of the two dietary groups (66VO, FO) are plotted against each other in different scatterplots for each sampling time at $3 \mathrm{~h}$ (A), $24 \mathrm{~h}$ (B) and $72 \mathrm{~h}(\mathrm{C})$ after the onset of initial disturbance. Data are the mean of 7 fish. Standard error is not plotted to simplify the graphical representation. $\beta$-actin was used as a housekeeping gene and regardless of dietary group all data values were referred to the expression level of AHR1 in control fish of the FO diet group. Black circles, up-regulated genes $(\mathrm{P}<0.05)$ in stressed fish of the 66VO diet; gray circles, down-regulated genes $(\mathrm{P}<0.05)$ in stressed fish of the 66VO diet; white circles, non-differentially regulated genes. 
Figure 1

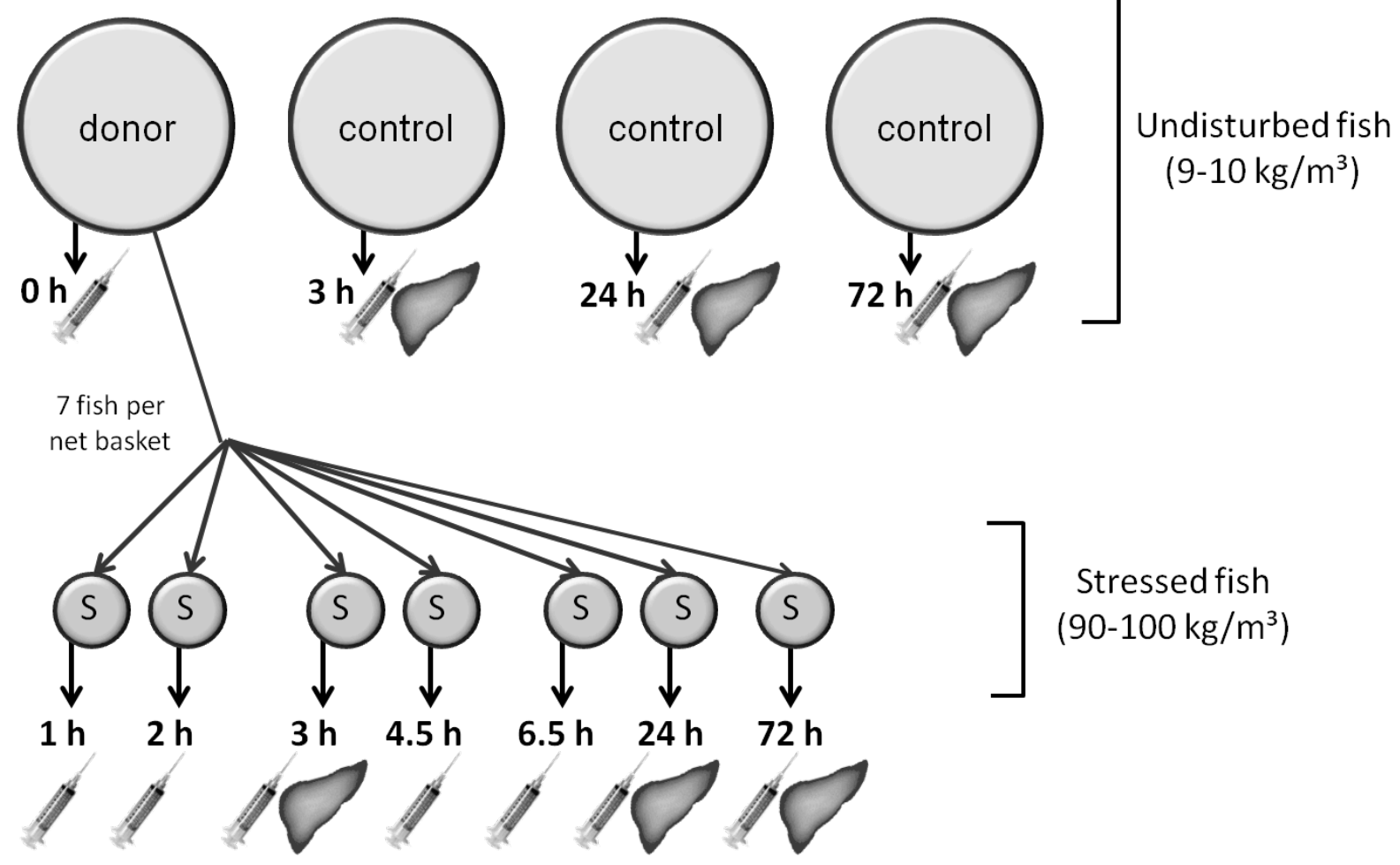


Figure 2
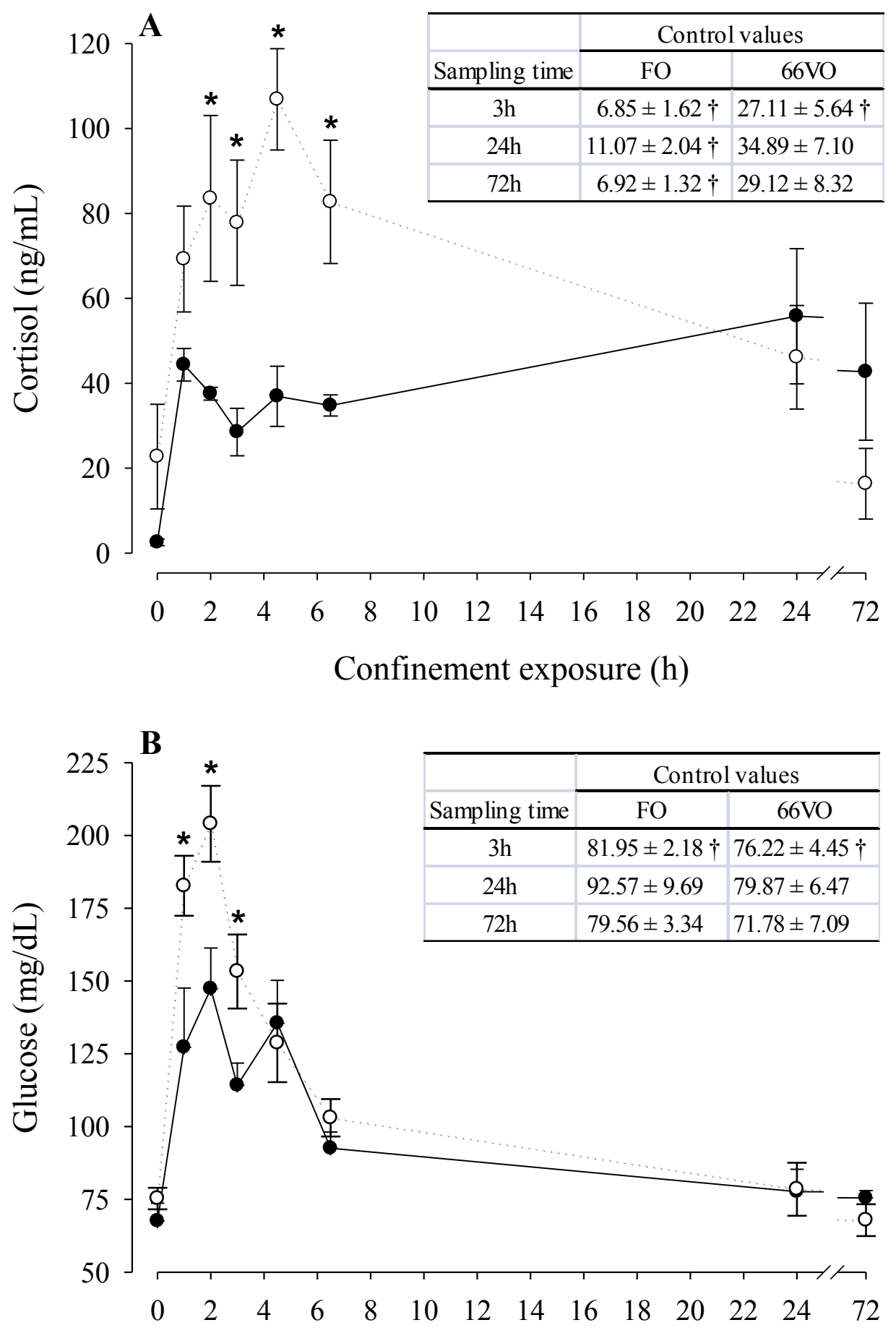

Confinement exposure (h) 
Figure 3
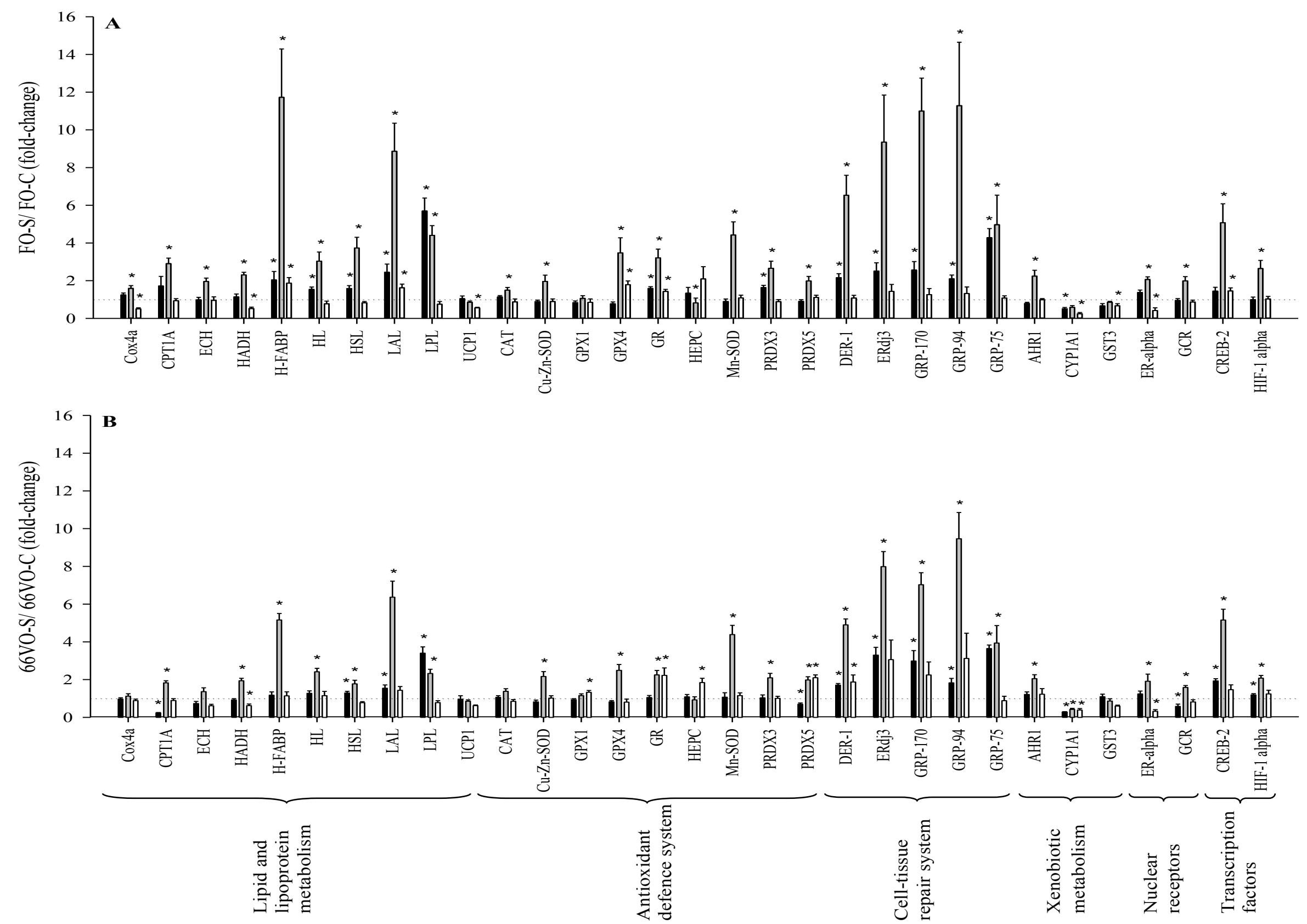
Figure 4
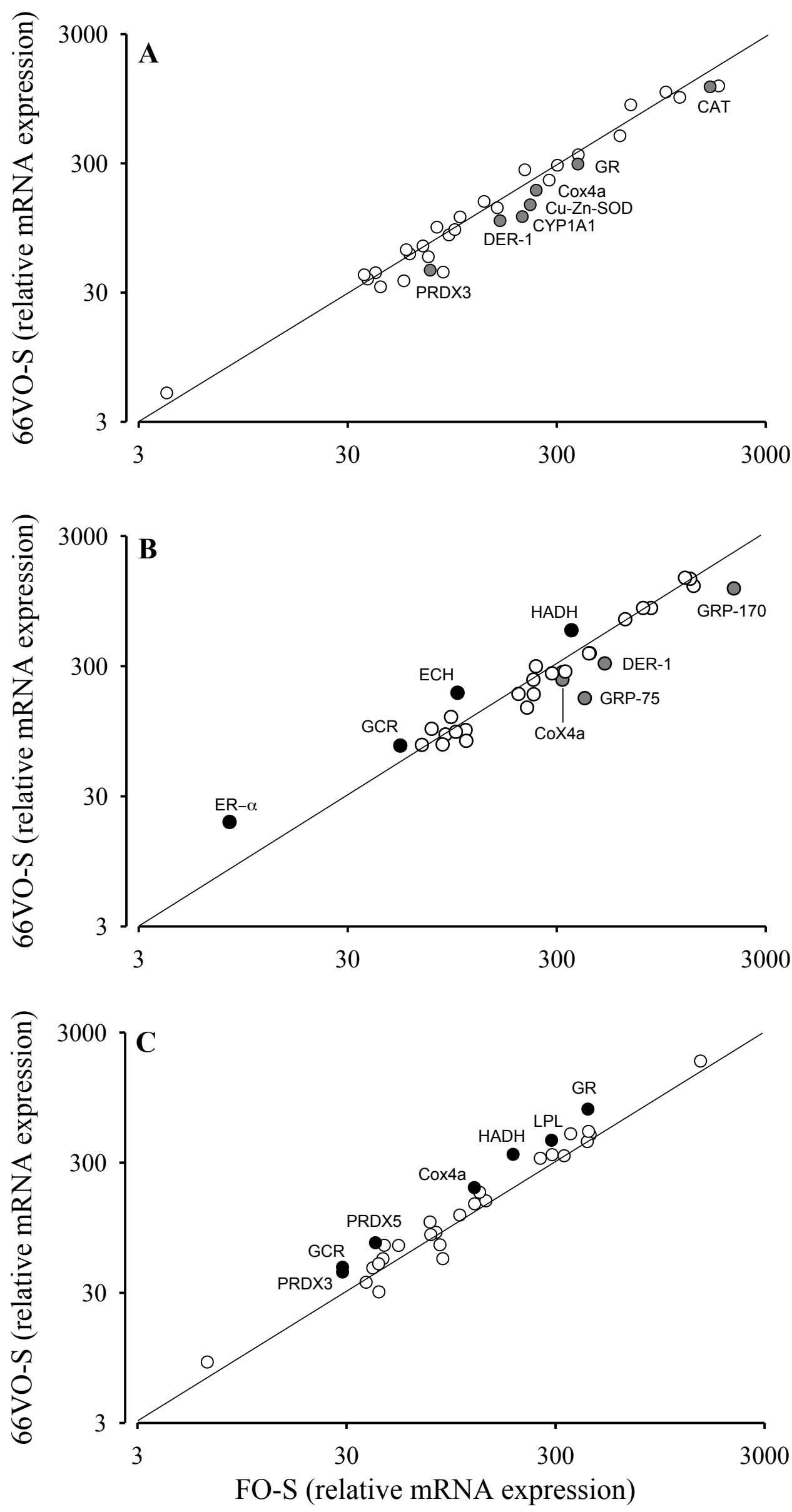
Supplemental Table 1. Classification of identified genes according to BLAST searches.

\begin{tabular}{|c|c|c|c|c|c|c|}
\hline Contig & $\mathrm{F}^{1}$ & size (nt) & Annotation $^{2}$ & Best match $^{3}$ & $\mathrm{E}^{4}$ & $\mathrm{CDS}^{5}$ \\
\hline C2_997 & 458 & 3067 & CAT & AAU44617 & 0 & $82-1671$ \\
\hline C2 270 & 526 & 787 & $\operatorname{Cox} 4 a$ & Q9I8U0 & $2 \mathrm{E}-106$ & $71-580$ \\
\hline C2_4920 & 97 & 2907 & CPT1A & ADH04490 & 0 & $<1-921$ \\
\hline C2_3305 & 135 & 1979 & CREB-2 & XP_003443277 & $4 \mathrm{E}-133$ & 271-1554 \\
\hline C2_17301 & 15 & 789 & DER-1 & XP 003443742 & $8 E-136$ & $132->788$ \\
\hline C2 3722 & 235 & 1553 & ECH & XP 003441229 & $3 E-180$ & $107-982$ \\
\hline C2_2999 & 265 & 2342 & ERdj3 & XP 003456324 & 0 & 117-1199 \\
\hline C2_49696 & 7 & 414 & GRP-170 & ADX97080 & $3 E-36$ & $<1->414$ \\
\hline C2_1490 & 399 & 2920 & GRP-94 & XP 003443932 & 0 & $240-2663$ \\
\hline C2 5598 & 299 & 1287 & GST3 & BAE06150 & $5 E-143$ & $365-1033$ \\
\hline C2_465 & 947 & 1219 & HADH & $\underline{\mathrm{ACO} 09265}$ & $5 \mathrm{E}-170$ & $98-1033$ \\
\hline C2_168 & 330 & 943 & H-FABP & ABY90513 & $2 \mathrm{E}-75$ & $125-526$ \\
\hline C2_4447 & 222 & 3462 & $\mathrm{HIF}-1 \alpha$ & $\underline{\text { ABD32158 }}$ & 0 & $273-2528$ \\
\hline C2 3027 & 222 & 3940 & LAL & ABY90514 & 0 & $65-1273$ \\
\hline C2_368 & 901 & 919 & $\mathrm{Cu}-\mathrm{Zn}-\mathrm{SOD}$ & $\underline{\mathrm{AAO} 015363}$ & $3 \mathrm{E}-100$ & $89-553$ \\
\hline C2_1642 & 276 & 1021 & Mn-SOD & AAW29024 & $7 E-162$ & $92-769$ \\
\hline
\end{tabular}

${ }^{1}$ Number of reads composing the assembled sequences.

${ }^{2}$ Gene identity determined through BLAST searches. CAT, catalase; Cox4a, cytochrome C oxidase subunit IV isoform 1; CPT1A, carnitine palmitoyltransferase 1A; CREB-2, cyclic AMP response elementbinding protein 2; DER-1, derlin 1; ECH, enoyl-CoA hydratase; ERdj3, ER-associated Hsp40 cochaperone; GRP-170, glucose-regulated protein, 170 kDa; GRP-94, glucose-regulated protein $94 \mathrm{kDa}$; GST3, glutathione S-transferase 3; HADH, hydroxyacyl-CoA dehydrogenase; H-FABP, heart-fatty acid binding protein; HIF-1 $\alpha$, hypoxia inducible factor-1 alpha; LAL, lysosomal acid lipase; Mn-SOD, superoxide dismutase [Mn]; $\mathrm{Cu}-\mathrm{Zn}-\mathrm{SOD}$, superoxide dismutase [Cu-Zn].

${ }^{3}$ Best BLAST-X protein sequence match (lowest E value).

${ }^{4}$ Expectation value.

${ }^{5}$ Codifying domain sequence. 
Supplemental Table 2. Forward and reverse primers for real-time PCR.

\begin{tabular}{|c|c|c|c|c|}
\hline Gene name & Symbol & $\begin{array}{l}\text { Accession } \\
\text { number }\end{array}$ & & Primer sequence \\
\hline \multirow[t]{2}{*}{$\beta$-actin } & \multirow[t]{2}{*}{$\beta$-actin } & \multirow{2}{*}{ X89920 } & F & TCC TGC GGA ATC CAT GAG A \\
\hline & & & $\mathrm{R}$ & GAC GTC GCA CTT CAT GAT GCT \\
\hline \multirow{6}{*}{$\begin{array}{l}\text { Aryl hydrocarbon } \\
\text { receptor } 1 \\
\text { Carnitine } \\
\text { palmitoyltransferase 1A } \\
\text { Catalase }\end{array}$} & \multirow[t]{2}{*}{ AHR1 } & \multirow[t]{2}{*}{ EU254480 } & $\mathrm{F}$ & CCT GGG ACT GAA CGC CGA AG \\
\hline & & & $\mathrm{R}$ & GCT AAG TGT TGG GAT GTG GTT GG \\
\hline & \multirow[t]{2}{*}{ CPT1A } & \multirow[t]{2}{*}{$\mathrm{JQ308822}^{1}$} & $\mathrm{~F}$ & GTG CCT TCG TTC GTT CCA TGA TC \\
\hline & & & $\mathrm{R}$ & TGA TGC TTA TCT GCT GCC TGT TTG \\
\hline & \multirow[t]{2}{*}{ CAT } & \multirow[t]{2}{*}{$\mathrm{JQ308823}^{1}$} & $\mathrm{~F}$ & TGG TCG AGA ACT TGA AGG CTG TC \\
\hline & & & $\mathrm{R}$ & AGG ACG CAG AAA TGG CAG AGG \\
\hline \multirow{2}{*}{$\begin{array}{l}\text { Cyclic AMP response } \\
\text { element-binding protein } 2\end{array}$} & \multirow[t]{2}{*}{ CREB-2 } & \multirow[t]{2}{*}{ JQ308824 ${ }^{1}$} & $\mathrm{~F}$ & TTC ATA TAA AGC CAG TCC ACC CTC TC \\
\hline & & & $\mathrm{R}$ & CTT CTC CAG CAG CAC CTC GTA G \\
\hline \multirow{4}{*}{$\begin{array}{l}\text { Cytochrome C oxidase } \\
\text { subunit IV isoform } 1 \\
\text { Cytochrome P450 1A1 }\end{array}$} & \multirow[t]{2}{*}{$\operatorname{Cox} 4 \mathrm{a}$} & \multirow[t]{2}{*}{$\mathrm{JQ308835}^{1}$} & $\mathrm{~F}$ & ACC CTG AGT CCA GAG CAG AAG TCC \\
\hline & & & $\mathrm{R}$ & AGC CAG TGA AGC CGA TGA GAA AGA AC \\
\hline & \multirow[t]{2}{*}{ CYP1A1 } & \multirow[t]{2}{*}{$\underline{\mathrm{AF} 011223}$} & $\mathrm{~F}$ & GCA TCA ACG ACC GCT TCA ACG C \\
\hline & & & $\mathrm{R}$ & CCT ACA ACC TTC TCA TCC GAC ATC TGG \\
\hline \multirow{2}{*}{ Derlin-1 } & \multirow{2}{*}{ DER-1 } & \multirow{2}{*}{$\underline{\mathrm{JQ308825}^{1}}$} & $\mathrm{~F}$ & ACT GCC TCG GTT GCC TTT CC \\
\hline & & & $\mathrm{R}$ & TGG CTG TCA CAA GTC TCC AGA TAT G \\
\hline \multirow[t]{2}{*}{ Enoyl-CoA hydratase } & \multirow[t]{2}{*}{$\mathrm{ECH}$} & $J Q 308826^{1}$ & $\mathrm{~F}$ & GCC CAA GAA GCC AAG CAA TCA G \\
\hline & & & $\mathrm{R}$ & CTT TAG CCA TAG CAG AGA CCA GTT TG \\
\hline ER-associated Hsp40 & ERdj3 & $\mathrm{JQ308827}^{1}$ & $\mathrm{~F}$ & AAC CGA CAG CAG CAG GAC AG \\
\hline co-chaperone & & & $\mathrm{R}$ & ACT TCT TCA AGC GTG ACC TCC AG \\
\hline Estrogen receptor alpha & ER- $\alpha$ & AF136979 & $\mathrm{F}$ & TCT AAG GGT CTG GAG CAC \\
\hline & & & $\mathrm{R}$ & TCG GTA TAG GGT CGG TTC \\
\hline Fatty acid binding protein, & H-FABP & JQ308834 ${ }^{1}$ & $\mathrm{~F}$ & CTG GGT GTG GGC TTC GCT AC \\
\hline heart & & & $\mathrm{R}$ & CTC TGT GTT CTT GAT GGT GCT CTG \\
\hline Glucocorticoid receptor & GCR & DQ486890 & $\mathrm{F}$ & CCA GGA CAG GTG CCG AAC G \\
\hline & & & $\mathrm{R}$ & TGG AGG AAC TGC TGC TGA ACC \\
\hline Glucose-regulated protein, & GRP-170 & JQ308821 ${ }^{1}$ & $\mathrm{~F}$ & CAG AGG AGG CAG ACA GCA AGA C \\
\hline $170 \mathrm{kDa}$ & & & $\mathrm{R}$ & TTC TCA GAC TCA GCA TTT CCA GAT TTC \\
\hline Glucose-regulated protein, & GRP-94 & JQ308820 ${ }^{1}$ & $\mathrm{~F}$ & AAG GCA CAG GCT TAC CAG ACA G \\
\hline $94 \mathrm{kDa}$ & & & $\mathrm{R}$ & CTT CAG CAT CAT CGC CGA CTT TC \\
\hline Glucose-regulated protein, & GRP-75 & DQ524993 & $\mathrm{F}$ & TCC GGT GTG GAT CTG ACC AAA GAC \\
\hline $75 \mathrm{kDa}$ & & & $\mathrm{R}$ & TGT TTA GGC CCA GAA GCA TCC ATG \\
\hline Glutathione peroxidase 1 & GPX1 & DQ524992 & $\mathrm{F}$ & GAA GGT GGA TGT GAA TGG AAA AGA TG \\
\hline & & & $\mathrm{R}$ & CTG ACG GGA CTC CAA ATG ATG G \\
\hline Glutathione peroxidase 4 & GPX4 & AM977818 & $\mathrm{F}$ & TGC GTC TGA TAG GGT CCA CTG TC \\
\hline & & & $\mathrm{R}$ & GTC TGC CAG TCC TCT GTC GG \\
\hline Glutathione reductase & GR & AJ937873 & $\mathrm{F}$ & TGT TCA GCC ACC CAC CCA TCG G \\
\hline & & & $\mathrm{R}$ & $\begin{array}{l}\text { GCG TGA TAC ATC GGA GTG AAT GAA GTC } \\
\text { TTG }\end{array}$ \\
\hline Glutathione & GST3 & JQ308828 ${ }^{1}$ & $\mathrm{~F}$ & CCA GAT GAT CAG TAC GTG AAG ACC GTC \\
\hline S-transferase 3 & & & $\mathrm{R}$ & CTG CTG ATG TGA GGA ATG TAC CGT AAC \\
\hline Hepatic lipase & HL & EU254479 & $\mathrm{F}$ & TTG TAG AAG GTG AGG AAA ACT G \\
\hline & & & $\mathrm{R}$ & GCT CTC CAT CAG ACC ATC C \\
\hline Hepcidin & HEPC & AM749960 & $\mathrm{F}$ & ACT CCT GGA AGA TGC CGT ATG C \\
\hline & & & $\mathrm{R}$ & AAC TTA CAC CTC CTG CGT CCA C \\
\hline Hormone-sensitive lipase & HSL & EU254478 & $\mathrm{F}$ & GCT TTG CTT CAG TTT ACC ACC ATT TC \\
\hline & & & $\mathrm{R}$ & GAT GTA GCG ACC CTT CTG GAT GAT GTG \\
\hline
\end{tabular}


Suppl. Table2. Continued.

\begin{tabular}{|c|c|c|c|c|}
\hline Gene name & Symbol & $\begin{array}{l}\text { Accession } \\
\text { number }\end{array}$ & & Primer sequence \\
\hline $\begin{array}{l}\text { Hydroxyacyl-CoA } \\
\text { dehydrogenase }\end{array}$ & HADH & $\mathrm{JQ308829}^{1}$ & $\begin{array}{l}\mathrm{F} \\
\mathrm{R}\end{array}$ & $\begin{array}{l}\text { GAA CCT CAG CAA CAA GCC AAG AG } \\
\text { CTA AGA GGC GGT TGA CAA TGA ATC C }\end{array}$ \\
\hline $\begin{array}{l}\text { Hypoxia inducible factor- } 1 \\
\text { alpha }\end{array}$ & $\mathrm{HIF}-1 \alpha$ & $\underline{J Q 308830}^{1}$ & $\begin{array}{l}\mathrm{F} \\
\mathrm{R}\end{array}$ & $\begin{array}{l}\text { CAG ATG AGC CTC TAA CTT GTG GAC } \\
\text { TTA GCA AGA ATG GTG GCA AGA TGA G }\end{array}$ \\
\hline Lipoprotein lipase & LPL & $\underline{\mathrm{AY} 495672}$ & $\begin{array}{l}\mathrm{F} \\
\mathrm{R}\end{array}$ & $\begin{array}{l}\text { CGT TGC CAA GTT TGT GAC CTG } \\
\text { AGG GTG TTC TGG TTG TCT GC }\end{array}$ \\
\hline Lysosomal acid lipase & LAL & $\mathrm{JQ308831}^{1}$ & $\begin{array}{l}\mathrm{F} \\
\mathrm{R}\end{array}$ & $\begin{array}{l}\text { TAC TAC ATC GGA CAC TCT CAA GGA AC } \\
\text { GTG GAG AAC GCT ATG AAT GCT ATC G }\end{array}$ \\
\hline Peroxiredoxin 3 & PRDX3 & GQ252681 & $\begin{array}{l}\mathrm{F} \\
\mathrm{R}\end{array}$ & $\begin{array}{l}\text { ATC AAC ACC CCA CGC AAG ACT G } \\
\text { ACC GTT TGG ATC AAT GAG GAA CAG ACC }\end{array}$ \\
\hline Peroxiredoxin 5 & PRDX5 & GQ252683 & $\begin{array}{l}\mathrm{F} \\
\mathrm{R}\end{array}$ & $\begin{array}{l}\text { GAG CAC GGA ACA GAT GGC AAG G } \\
\text { TCC ACA TTG ATC TTC TTC ACG ACT CC }\end{array}$ \\
\hline $\begin{array}{l}\text { Superoxide dismutase } \\
{[\mathrm{Cu}-\mathrm{Zn}]}\end{array}$ & $\mathrm{Cu}-\mathrm{Zn}-\mathrm{SOD}$ & $\mathrm{JQ308832}^{1}$ & $\begin{array}{l}\mathrm{F} \\
\mathrm{R}\end{array}$ & $\begin{array}{l}\text { TCA CGG ACA AGA TGC TCA CTC TC } \\
\text { GGT TCT GCC AAT GAT GGA CAA GG }\end{array}$ \\
\hline $\begin{array}{l}\text { Superoxide dismutase } \\
\text { [Mn] }\end{array}$ & Mn-SOD & $\mathrm{JQ308833}^{1}$ & $\begin{array}{l}\mathrm{F} \\
\mathrm{R}\end{array}$ & $\begin{array}{l}\text { CCT GAC CTG ACC TAC GAC TAT GG } \\
\text { AGT GCC TCC TGA TAT TTC TCC TCT G }\end{array}$ \\
\hline Uncoupling protein 1 & UCP1 & FJ710211 & $\begin{array}{l}\mathrm{F} \\
\mathrm{R}\end{array}$ & $\begin{array}{l}\text { GCA CAC TAC CCA ACA TCA CAA G } \\
\text { CGC CGA ACG CAG AAA CAA AG }\end{array}$ \\
\hline
\end{tabular}

${ }^{\mathrm{T}}$ New gilthead sea bream sequences uploaded to GenBank 